DOI (Issue) : https://doi.org/10.31108/3.2019.2.8.6

\title{
159.942 .2
}

Чуйко Галина Василівна, кандидат філологічних наук, доцент кафедри психології Чернівецького національного університету ім. Юрія Федьковича e-mail: halynka2244@ukr.net

Чаплак Ян Васильович, кандидат психологічних наук, доцент кафедри психології Чернівецького національного університету ім. Юрія Федьковича e-mail: yan.chaplak@gmail.com

\section{ПСИХОЛОГІЧНЕ БЛАГОПОЛУЧЧЯ ЛЮДИНИ ЯК ФЕНОМЕН СУЧАСНОЇ ПСИХОЛОГІї}

\section{Анотація}

Стаття присвячена аналізу тлумачення феномену психологічного благополуччя у позитивній $i$ пострадянській психології, актуальність чого зумовлена як зростаючим інтересом психологічної науки до поняття психологічного благополуччя, так $i$ впливом цьього відчуття на життєдіяльність людини.

Констатується, що, не дивлячись на величезну кількість теоретичних $i$ емпіричних досліджень психологічного благополуччя $у$ зарубіжній та вітчизняній психологї та суміжних науках, иілісне й узагальнене пояснення даного феномену у науковому обігу досі відсутнє, а сучасна психологія у своєму розумінні психологічного благополуччя базується на поглядах на нього представників двох основних підходів до тлумачення благополуччя: гедоністичного та евдемонічного: Е.Дінера та К.Ріфф. Це проявляється, зокрема, в тому, що, навіть представляючи «власне» розуміння феномену психологічного благополуччя, науковиі засновують його на відтворенні в тій чи іншій мірі та формі поглядів на суть і структуру психологічного благополуччя Дінера та Ріфф.

Під психологічним благополуччям ми суб'єктивно схильні розуміти суб'єктивне відчуття, що життя йде саме так, як має бути; все, щзо з 
людиною стається, відбувається закономірно, як належить; сама людина - на своєму місиі та зовні та внутрішньо, відповідає кожному моменту свого життя. Це відчуття, щзо дає людині дущевний спокій $і$ надію на краще, $\epsilon$ результатом ї̈ оцінки та сформованого ставлення до різних (зовнішніх $i$ внутрішніх) обставин свого життя.

Зроблено висновок про різницю між зарубіжною позитивною психологією та пострадянською у тлумаченні поняття психологічного благополуччя. Зокрема, позитивна психологія та ї̈ представники аналізують переважно його структуру та найрізноманітніші чинники, здатні вплинути на появу відчуття психологічного благополуччя, тоді як пострадянська психологія схильна зосереджуватися переважно на спробах включити психологічне благополуччя до структури феномену загального благополуччя, щзо може приводити до позбавлення трунтовного самостійного аналізу поняття психологічного благополуччя.

Ключові слова: суб’єктивне і психологічне благополуччя, евдемонічний, гедоністичний, самореалізація, щуастя, задоволеність життям.

Чуйко Галина Васильевна, кандидат филологических наук, доцент кафедры психологии Черновицкого национального университета имени Юрия Федьковича

Чаплак Ян Васильевич, кандидат психологических наук, доцент кафедры психологии Черновицкого национального университета имени Юрия Федьковича

\section{ПСИХОЛОГИЧЕСКОЕ БЛАГОПОЛУЧИЕ ЧЕЛОВЕКА КАК ФЕНОМЕН СОВРЕМЕННОЙ ПСИХОЛОГИИ}

\section{Аннотация}

Статья посвящена анализу толкования феномена психологчческого благополучия в позитивной и постсоветской психологии, актуальность чего обусловлена как растущуим интересом психологчческой науки к понятию психологического благополучия, так и влиянием этого чувства на 
жизнедеятельность человека.

Констатируется, что, несмотря на огромное количество теоретических и эмпирических исследований психологического благополучия в зарубежной и отечественной психологии и смежных науках, цуелостное $u$ обобщенное объяснение данного феномена в научном обороте до сих пор отсутствует, а современная психология в своем понимании психологического благополучия базируется на взглядах на него представителей двух основных подходов к толкованию благополучия: гедонистического и евдемонического: Э.Динера и К.Рифф. Это проявляется, в частности, в том, что, даже представляя «собственное» понимание феномена психологического благополучия, ученые основывают его на воспроизведении в той или иной степени и форме взглядов на сущзность и структуру психологического благополучия Динера и Рифф.

Под психологическим благополучием мы субъективно склонны понимать субъективное ощущение, что жизнь идет именно так, как должно быть; все, что с человеком происходит, происходит закономерно, как положено; сам человек - на своем месте, как снаружи, так и внутри, соответствует каждому моменту своей жизни. Это ощущуение, дающее человеку душевный покой и надежду на лучшее, является результатом его оченки $u$ сформированного отношения $\kappa$ различным (внешним и внутренним) обстоятельствам своей жизни.

Сделан вывод о разнице между зарубежной позитивной психологией и постсоветской в толковании понятия психологического благополучия. $B$ частности, позитивная психология и ее представители анализируют преимущуественно его структуру и различные факторы, способные повлиять на появление ощущения психологического благополучия, тогда как постсоветская психология склонна сосредотачиваться преимущественно на попытках включить психологчческое благополучие в структуру феномена общуего благополучия, может приводить $к$ лищению основательного самостоятельного анализа понятия психологического благополучия. 
Ключевые слова: субъективное и психологическое благополучие, эвдемонический, гедонистический, самореализачия, счастье, удовлетворенность жизнью.

Chuyko Halyna Vasylivna, candidate of philological sciences, associate Professor of psychology department, Yuriy Fedkovych Chernivtsi National University

Chaplak Yan Vasylyovych, candidate of psychological sciences, associate Professor of psychology department, Yuriy Fedkovych Chernivtsi National University

\section{PSYCHOLOGICAL WELL-BEING OF HUMAN AS A PHENOMENON OF MODERN PSYCHOLOGY}

\section{Summary}

The article is deals with the analysis of the interpretation of the phenomenon of psychological well-being in the positive and post-soviet psychology. The relevance of investigation is due to the increasing interest of psychological science to the concept of psychological well-being, and influence of this feeling on the vital activity of man.

It is stated that despite the great number of theoretical and empirical studies of psychological well-being in foreign and domestic psychology and related sciences, still there is no comprehensive and general explanation of this phenomenon in scientific use. Modern psychology in the understanding of psychological well-being based on the views on it representatives of two basic approaches to the interpretation of well-being: hedonistic and eudemonic: E. Diner and K. Riff.

A further analysis of the phenomenon of psychological well-being which occurs in the post-soviet space testifies as the fact that in the views of researchers somehow combine both directions in the understanding of well-being so as excessive adherence to these interpretations, which prevents scientists to go beyond the views of E. Diner and K. Riff (their closest mediators and followers) on, may be, new (different) level of understanding of the concept. This is manifested, in particular, by the fact, that even representing the "proper" understanding of the phenomenon of psychological well- 
being, scientists establish it on reproducing to one degree or another and in the form of the views of Diner and Riff on the essence and structure of psychological wellbeing.

We are subjectively inclined to understand the psychological well-being as the subjective feeling that life goes exactly as it should be; everything that happens to a person comes logically, as it should be; the person himself - in his place; both externally and internally, corresponds to every moment of his life. This feeling, which gives a person peace of mind and hope for the best, is the result of her assessment and the formed attitude to various (external and internal) circumstances of her life.

The conclusion about the difference between foreign positive psychology and post-soviet in the interpretation of the concept of psychological well-being is made. In particular, positive psychology and its representatives analyze mainly its structure and the variety of factors that can influence on the appearance of a sense of psychological well-being, while post-soviet psychology tends to focus primarily on attempts to include psychological well-being to the structure of the phenomenon of general well-being, which can lead the concept of psychological well-being to deprivation of detailed independent analysis.

Keywords: subjective and psychological wellbeing, eudaimonic, hedonic, selfrealization, happiness, life satisfaction.

Постановка проблеми. Психологічне благополуччя поступово займає місце однієї з найзначніших категорій сучасної психологічної науки, хоча його досягнення за умови сучасної нестабільності соціуму та ситуації в країні залишається доволі проблематичним, проте, бажаним, що пояснюється тими позитивними змінами, які супроводжують це відчуття, серед яких зростання у людини віри в себе та довіри до світу й інших людей чи не найважливіше.

Важливість вивчення психологічного благополуччя зумовлена не лише різним сприйняття світу і ставленням до нього, залежно від ступеня суб'єктивності його переживання людиною, але й, зокрема, впливом цього відчуття на iї самопочуття та поведінку, процес і результат діяльності 
особистості.

Аналіз досліджень і публікацій. До аналізу різних аспектів психологічного благополуччя з часу виникнення інтересу до даного феномену в позитивній психології зверталися багато вчених, зокрема Н.Бредберн, Е.Дінер, К.Ріфф, М.Селігман, М.Аргайл, Ш.Стайл, П.П. Фесенко, Л.В. Куликов, Р.М. Шаміонов, О.С. Ширяєва й ін. Та, не дивлячись на те, що вченими була розглянута дуже велика кількість різноманітних факторів, які впливають на суб'єктивну задоволеність життям чи благополуччя людей, у тому числі в лонгітюдних дослідженнях, досі не з'явилося комплексне і цілісне пояснення цього феномену.

Мета цієї статті - проаналізувати теоретичні аспекти тлумачення поняття психологічного благополуччя в психології.

Виклад основного матеріалу. У позитивній психології традиційно виділяються два основні підходи до розуміння психологічного благополуччя: гедоністичний і евдемонічний, причому основним представником першого вважають Е.Дінера, який, наслідуючи певною мірою Н.Бредберна, під суб’єктивним благополуччям по суті розуміє комплексне переживання людини, що iї життя складається добре [14] (у Н.Бредберна це означало досягнення балансу між позитивними та негативними емоціями, що супроводжують життєві події) [16].

Суб’єктивне благополуччя Е.Дінером визначається як «широка категорія феноменів, що полягають в емоційній реакції людей, їх задоволеності окремими сферами життя, а також в їх судженнях про якість життя в цілому» [13]. При цьому задоволеність життям (як рефлексивне судження людини, що іiі життя іде добре) вважається когнітивною, а баланс позитивних і негативних емоцій, які людина переживає протягом певного відрізку часу (що вона насправді відчуває), - емоційною (афективною) стороною суб'єктивного благополуччя і двома різними способами комплексної оцінки життя людини. Суб’єктивне благополуччя людини, за Дінером, означає, що иї життя є бажаним, приємним і хорошим [16]. Саме осмислено оцінюючи своє життя та досвід, 
пов’язані 3 умовами життя соціуму, соціальними стосунками, своєю можливістю «функціонувати у здоровий спосіб», людина відчуває певний рівень суб’єктивного благополуччя [13], яке має три характерні ознаки: суб’єктивність (бо об’єктивні фактори, що потенційно можуть впливати на нього, не $є$ «необхідною частиною його»), позитивність (це не тільки відсутність негативних переживань, a саме наявність позитивних) i глобальність оцінки усіх аспектів життя людини (це комплексне судження) [16]. Причому суб’єктивне благополуччя можна розглядати як результат, до якого люди прагнуть, і як функціональний процес, який допомагає людям у досягненні інших цілей.

Крім того, згідно Е.Дінера, поняття «щастя», важливим аспектом чого є переживання позитивних емоцій, та «суб'єктивного благополуччя» в значній мірі синонімічні, оскільки більшість людей вважають досягнення щастя кінцевою метою, до якої вони прагнуть [16].

Близьку до цього розуміння думку висловлює М.Аргайл, вважаючи, що щастя (або благополуччя) - це єдиний фактор людського досвіду, який часто визначають як відчуття радості, що складається з трьох відносно незалежних факторів: задоволеності життям, позитивних емоцій і відсутності негативних переживань [1, с.42].

На думку ж Ш.Стайл, щастя i задоволеність життям - показники самореалізації і загального благополуччя. Проте справжнього процвітання ми зможемо досягти, лише коли будуть задоволені всі наші основні психологічні потреби. Тоді як суб’єктивне благополуччя (subjective well-being) - це те, наскільки людина щаслива з іï (суб’єктивної) точки зору, те, як вона оцінює своє життя. Воно означає, що людині подобається їі життя, що вона вважає, що живе добре, і передбачає поєднання задоволеності життям і позитивних емоцій, найбільше залежачи від «того, як ми будуємо своє життя» [8]. Стайл не схильна ототожнювати ці поняття, i ми цілком погоджуємося 3 iї думкою, що психологічне благополуччя свідчить, що людина «повноцінно функціонує психологічно, навіть якщо у даний момент вона не почувається щасливою» [8]. 
Евдемонічний підхід до тлумачення психологічного благополуччя започаткований К.Ріфф, яка під психологічним благополуччям розуміє «суб'єктивне самовідчуття цілісності й осмисленості індивідом свого буття» [12]. Ріфф розробила багатовимірну модель психологічного благополуччя, яка складається 3 таких компонентів, що визначають екзистенційні переживання людини: позитивні стосунки з іншими (здатність до теплих, довірчих відносин 3 навколишніми, до турботи про їх благополуччя, співпереживання, до підтримання стосунків шляхом взаємних поступок i досягнення згоди), самоприйняття (позитивне ставлення до себе, що передбачає прийняття різних (і негативних) сторін власного Я, у тому числі у минулому житті), автономність (здатність проявляти самостійність, незалежність у протистоянні соціальному тиску, самовизначення та самоконтроль поведінки, орієнтуватися в самооцінці на власні принципи і критерії), компетентність (екологічна майстерність) у керуванні середовищем (реальна можливість управляти оточенням, ефективно реалізуючи свої можливості задля поліпшення зовнішніх обставин і умов діяльності, що задовольняє особисті потреби і базується на екзистенційних цінностях при досягненні поставленої мети), наявність мети в житті (інтенційна життєва спрямованість на досягнення мети, що є надважливою цінністю для особистості, і послуговування зв'язком минулого, теперішнього та майбутнього часів життя людини), особистісний ріст (передбачає постійне самоздійснення людини і реалізацію нею своїх потенцій, відкритість досвіду і позитивним змінам, самопізнання, усвідомлення свого росту і досконалості) [15]. Отже, психологічне благополуччя стосується як організації та змісту внутрішнього світу людини, так і їі поведінки та діяльності, що зумовлюють це відчуття та ілюструють його переживання.

Вищеназвані підходи до розуміння психологічного благополуччя Ш.Стайл називає двома типами (станами) щастя: хвилинним, яке проявляється як радість, задоволення і насолода від повсякденних занять, і відчуттям задоволеності, яке триває значно довше, приносить глибоке почуття благоденства, передбачає розкриття справжнього потенціалу та самореалізацію 
особистості. Проте вчена не радить віддавати перевагу одному з них: «якщо ми почнемо порівнювати одне з іншим, то упустимо найголовніше: нам потрібне i миттєве, і тривале щастя. Часто те, що дає насолоду в наших діях, стає ключем до розкриття нашої здатності ставити та досягати більш цікавих і значимих цілей і реалізовувати свій потенціал» [8].

Подальший аналіз феномену психологічного благополуччя, що відбувається на пострадянському просторі, засвідчує як те, що в поглядах дослідників певним чином комбінуються обидва напрямки у розумінні благополуччя, так і надмірну прихильність до цих тлумачень, що заважає науковцям вийти за рамки поглядів Е.Дінера та К.Ріфф (їх найближчих посередників і послідовників) на, можливо, новий (інший) рівень розуміння поняття.

Найбільш відомим тут залишається дослідження психологічного благополуччя П.П. Фесенком, згідно якого, психологічне благополуччя - це «інтегральний показник ступеня спрямованості людини на реалізацію основних компонентів позитивного функціонування (особистісного росту, самоприйняття, керування середовищем, автономії, мети в житті, позитивних стосунків з оточуючими), а також ступеня реалізованості цієї спрямованості, що суб'єктивно виражається у відчутті щастя, задоволеності собою і власним життям» [9], який визначається не стільки раціонально-об'єктивно, скільки емоційно. Розуміння Фесенком психологічного благополуччя не лише як «спрямованості людини на реалізацію основних компонентів позитивного функціонування», але й «ступені реалізованості цієї спрямованості, що суб'єктивно виражається у відчутті щастя, задоволеності собою і власним життям» логічно привело вченого до виділення «актуального» та «ідеального» психологічного благополуччя та висновку, що «чим вищий рівень актуального психологічного благополуччя, тим вища осмисленість життя і тим більше актуальне благополуччя наближається до ідеального психологічного благополуччя за своєю структурою» [9]. Не важко помітити відповідність даного визначення та тлумачення психологічного благополуччя як процесу i 
результату самореалізації особистості поглядам К.Ріфф і перекличку з ідеями про реальне та ідеальне Я К.Роджерса.

На думку Р.М. Шаміонова, суб’єктивне благополуччя - це поняття, що виражає «власне ставлення людини до своєї особистості, життя і процесів, що мають важливе значення для особистості 3 погляду засвоєних нормативних уявлень про зовнішнє і внутрішнє середовище і характеризується відчуттям задоволеності» [7]; це психологічний феномен, що втілює природне прагнення людини до внутрішньої рівноваги, комфорту, відчуття щастя, будучи регулятором життєдіяльності особистості та критерієм ऑii «позитивної інтегральної детермінації». Додамо, що поняття «ставлення» автор витлумачує як соціальну установку (attitude) 3 відповідними складовими. При цьому Шаміонов зазначає, що благополуччя пов'язане не стільки 3 потребами та їх задоволенням, скільки із суб'єктивним ставленням особистості до можливості їх задоволення, подій життя і самої себе [10, с.39-41].

Г.Л. Пучкова розглядає суб'єктивне благополуччя як інтегральне психологічне утворення, що включає в себе оцінку й ставлення людини до власного життя та себе. Центральне значення для дослідження цього психологічного феномену надається потребам та цінностям, їх усвідомленню, поведінці людини та результату діяльності з їх реалізації, який викликає стан задоволеності, щастя, позитивні емоції. Увага тут приділяється відповідності актуальних потреб суб’єктивним можливостям людини з їх задоволення [6].

Теоретично проаналізувавши складові суб’єктивного благополуччя, Г.Л. Пучкова виділила такі його компоненти: когнітивний (уявлення людини про благополуччя, про майбутнє), емоційно-оціночний (задоволеність минулим та наявним, сподівання на майбутнє, позитивне ставлення до інших, себе та власного здоров’я), мотиваційно-поведінковий (наявність життєвої мети, спрямованість на особистісний ріст, контроль за обставинами) [7]. Закономірний висновок, що, по-перше, ця дослідниця розуміє благополуччя як соціальну установку, по-друге, ii характеристики компонентів суб'єктивного благополуччя також не вільні від суттєвого впливу поглядів К.Ріфф. 
О.С. Бочарова суб'єктивне благополуччя також тлумачить як соціальну установку особистості - складне соціально-психологічне утворення, що включає емоційні, когнітивні та конативні компоненти і формується в процесі соціально-психологічної діяльності, в системі реальних ставлень особистості до об’єктів навколишньої дійсності, складаючись на основі соціальнопсихологічних установок, цінностей, стратегій поведінки [2].

О.М. Леонтьєв пропонує поняття «особистісний потенціал», співвідносне 3 психологічним благополуччям. Особистісний потенціал, за О.М. Леонтьєвим, є інтегральною характеристикою рівня особистісної зрілості, проявляючись через самодетермінацію особистості, тобто діяльність, відносно вільну від умов цієї діяльності - як зовнішніх, так і внутрішніх. До діючої на нас системи факторів, за Леонтьєвим, ми можемо адаптуватися, але можемо і трансцендувати цю систему, включивши механізми самодетермінації. I «саме в трансцендентному ставленні до власного потоку життя, - на думку вченого, перш за все і проявляється особистісна зрілість як вираження особистісного потенціалу» [5]. Особистісний потенціал відображає міру подолання особистістю наявних обставин (у тому числі несприятливих умов її розвитку) i самої себе.

Особистісний потенціал О.М. Леонтьєва, пов'язаний з життєстійкістю людини (С.Мадді), на нашу думку, можна вважати передумовою відчуття людиною психологічного благополуччя, оскільки він дає можливість психологічно легше і мужньо сприймати життєві проблеми та перешкоди на шляху до мети, завдяки чому редукується переживання негативних емоцій як кількісно, так і в плані їх інтенсивності, крім того, рівень психологічної зрілості особистості (зумовлений особистісним потенціалом) дає ій можливість відповідально ставитися до процесу і результатів свого життя, намагатися здійснювати керівництво ним у теперішньому та зі спрямуванням у майбутнє.

Досить спірними, як на нас, є погляди на психологічне благополуччя Г.В. Вороніної, яка, по суті, зводить його до поняття «здоров'я», значно обмежуючи феномен психологічного благополуччя за змістом, і вважає, що на різних рівнях 
простору буття людини, сформованих у різних типах діяльності, закладаються внутрішні інтенції (свідомі і несвідомі ресурсні установки), що об’єднуються в якісні своєрідно-ієрархічні рівні психологічного благополуччя людини: психосоматичного здоров'я, соціальної адаптації, психічного здоров'я та психологічного здоров'я. Вчена вважає, що кожен наступний рівень, що формується в процесі розвитку і виховання, дає людині нове бачення самої себе, світу і себе в світі і, в силу цього, нові можливості для реалізації задумів, творчої активності, великий «ступінь свободи» для вибору шляхів адекватного реагування [3, с.47].

Зазначимо, що нам важко погодитися як 3 таким тлумаченням психологічного благополуччя, так і з поділом його на виділені Г.В. Вороніною piвнi.

Дослідження Л.В. Куликова, що стосується аналізу благополуччя особистості, якнайліпше ілюструє як думку самого вченого, що «невизначеність і нечіткість», що стосуються суб’єктивного світу особистості, «є бар'єром перш за все для психологів», так і складність тлумачення даного феномену. За Куликовим, психологічне благополуччя (душевний комфорт) один зі складників благополуччя особистості (поряд із соціальним, духовним, фізичним i матеріальним), що визначається як «узгодженість психічних процесів і функцій, відчуття цілісності, внутрішньої рівноваги» [4]. До структури («досить складної») психологічного благополуччя Куликов відносить когнітивний і емоційний компоненти, а також «актуальну успішність поведінки i діяльності, задоволення міжособистісними зв'язками, спілкуванням» (очевидно, поведінковий компонент), причому когнітивний компонент благополуччя виникає при «цілісній відносно несуперечливій картині світу в суб’єкта, розумінні наявної ситуацій», а емоційний, на думку вченого, «проявляється як переживання, що поєднує почуття, зумовлені успішним (чи ні) функціонуванням особистості» [4].

На нашу думку, незгода $з$ таким розумінням благополуччя виникає вже на етапі поділу благополуччя особистості на складові, відділення духовного від 
психологічного, і тлумачення поняття психологічного благополуччя (тут, як на нас, більше підходить саме «психічне»). Далі ситуація лише ускладнюється, поперше, через визначення двох компонентів психологічного благополуччя, які викликають надто багато запитань (наприклад, не можемо погодитися, як щодо того, що «цілісна» картина світу $є$ лише у психологічного благополучних людей, так i щодо впливу цієї обставини безпосередньо на відчуття благополуччя, а також щодо залежності благополуччя від почуттів з приводу «успішності (чи неуспішності!?) функціонування всієї особистості» (зазначимо також, що якщо виходити з «успішності функціонування всієї особистості» як передумови відчуття благополуччя, воно стане практично недосяжним, як i самоактуалізація (за А.Маслоу). Крім того, автор (уже виділивши два традиційні компоненти у структурі психологічного благополуччя) додає до них «наявність ясних цілей, успішність реалізації планів діяльності і поведінки, наявність ресурсів і умов для досягнення цілей» [4] та ін. 3 одного боку, це посправжньому ілюструє складність і багатогранність розглядуваного поняття i розуміння цього Куликовим, з іншого, - те, що вчений так і не систематизував, не узагальнив погляд на структуру і зміст поняття «благополуччя», тому що інтерпретація поняття «суб'єктивне благополуччя» як «узагальненого i відносно стійкого переживання, що має особливу значимість для особистості» [4] насправді визначенням не є, оскільки не відрізняє його серед інших переживань людини.

О.С. Ширяєвою психологічне благополуччя визначається як сукупність необхідних особистісних ресурсів, що забезпечує суб'єктивну та об'єктивну успішність особистості в системі «суб'єкт-середовище» (залишається незрозумілим, що це за «ресурси» і звідки вони з’являються). У якості складових психологічного благополуччя визначені такі п'ять компонентів: афективний (баланс позитивних i негативних афективних переживань); компонент, пов'язаний 3 метапотребами (особистісний зріст, міра самореалізації); світоглядний (наявність цілей у житті); інтрарефлексивний (самоприйняття); інтеррефлексивний (компетентність у відношеннях 3 
навколишнім середовищем) [11]. Досить закономірно, що цей підхід, при всій його зовнішній і змістовній привабливості, нагадує компоненти психологічного благополуччя К.Ріфф, тільки по-іншому названі.

Отже, виявляється, що більшість досліджень психологічного благополуччя на пострадянському просторі, представляючи «власне» розуміння цього поняття, насправді в тій чи іншій мірі використовують ідеї щодо тлумачення даного феномену Е.Дінера чи К.Ріфф.

На нашу думку (цілком суб’єктивну), психологічне благополуччя - це не лише суб'єктивне відчуття людини, що іiі життя складається (йде) добре (за Е.Дінером), це відчуття, що життя йде саме так, як має бути, все, що з людиною стається, відбувається закономірно, як належить, сама людина - на своєму місці та, як зовні, так і внутрішньо, відповідає кожному моменту свого життя. Відчуття благополуччя $\epsilon$ результатом оцінки та сформованого ставлення людини до різних (зовнішніх і внутрішніх) обставин свого життя. Психологічне благополуччя дає людині душевний спокій, з одного боку, з іншого, - створює основу для почуття надії: одній людині - на шанс гідно прожити завтрашній день, іншій - на досить удале, успішне і відносно безхмарне майбутнє. За мірою прояву, психологічне благополуччя задовольняє відповідні психологічні потреби людини, забезпечує душевний спокій, підтримує і зміцнює самоповагу особистості, вмотивовує їі на подальші досягнення та спроби самоздійснення.

Методологічне та загальнонаукове значення роботи полягає в узагальненні тлумачення феномену психологічного благополуччя в сучасній психології.

Можна висловити припущення, що розуміння поняття психологічного благополуччя не $\epsilon$ абсолютним на всі часи, що його тлумачення має змінюватися як залежно від критичності (кризовості, травматичності) ситуації, у якій розвивається країна і суспільство (i як іï переживає сама людина), так i від загострення екзистенційних проблем життя самої особистості.

Аналіз наукової літератури 3 проблеми психологічного благополуччя дозволяє зробити такі основні висновки: позитивна психологія аналіз 
психологічного благополуччя спрямовує переважно на його структуру, складові та основні чинники, що ймовірнісно можуть вплинути на виникнення і характер цього відчуття, у тому числі життєві сфери, у яких особистість може задовольнити свої потреби чи реалізувати себе, емпірично перевіряючи існування зв'язку між психологічним благополуччям та найрізноманітнішими об'єктивними та суб'єктивними факторами; пострадянська психологія, демонструючи, з одного боку, залежність свого тлумачення психологічного благополуччя від поглядів Е.Дінера та К.Ріфф, з іншого, - зосереджується в основному на включенні психологічного благополуччя у структуру загального поняття «благополуччя», яке передбачає існування інших видів благополуччя, зміщуючи акцент розгляду на це узагальнююче поняття i позбавляючи грунтовного самостійного аналізу поняття психологічного благополуччя.

Перспективу подальших наукових розвідок у визначеному напрямку бачимо в емпіричному дослідженні феномену психологічного благополуччя.

\section{Список використаних джерел}

1. Аргайл М. Психология счастья / М. Аргайл. - 2-е изд. - СПб.: Питер, 2003. - 271 с. - (Серия «Мастера психологии»).

2. Бочарова Е.Е. Взаимосвязь ценностных ориентаций, стратегий поведения и субъективного благополучия личности : автореф. дисс. ... канд. психол. наук : 19.00.05 / Е.Е. Бочарова. - Саратов, 2005. - 23 с.

3. Воронина А.В. Оценка психологического благополучия школьников в системе профилактической и коррекционной работы психологической службы : автореф. ... канд. псих. наук : 19.00.04 / А.В. Воронина. - Иркутск, 2002. - 28 с.

4. Куликов Л.В. Детерминанты удовлетворенности жизнью / Л.В. Куликов // Общество и политика / Ред. В.Ю. Большаков. - СПб.: Изд-во С.Петербургского ун-та, 2000. - С.476-510.

5. Леонтьев Д.А. Личностное в личности. Личностный потенциал как основа самодетерминации / Д.А. Леонтьев // Ученые записки кафедры общей психологии МГУ им. М.В.Ломоносова / Под ред. Б.С. Братуся, Д.А. Леонтьева. - Вып. 1. - М.: Смысл, 2002. - С.56-65. 
6. Пучкова Г.Л. Субъективное Благополучие как фактор самоактуализации личности [Электронный ресурс] : дис. ...канд. психол. наук : 19.00.01 / Г. Л. Пучкова - М. : РГБ, 2003. - 163 с.

7. Смолева Е.О. Удовлетворенность жизнью и уровень счастья: взгляд социолога [Текст] : монография / Е.О. Смолева, М.В. Морев; под науч. рук. д.э.н. А.А. Шабуновой. - Вологда : ИСЭРТ РАН, 2016. - 164 с. - (Проблемы эффективности государственного управления).

8. Стайл Ш. Позитивная психология. Что делает нас счастливыми, оптимистичными и мотивированными / Ш.Стайл. - М.: Претекст, 2013. - 326 с.

9. Фесенко П.П. Осмысленность жизни и психологическое благополучие личности : автореф. дис. ... канд. психол. наук: 19.00.01 / П.П. Фесенко. - М., 2005. $-24 \mathrm{c}$.

10. Ширяева О.С. Психологическое благополучие личности в экстремальных условиях жизнедеятельности [Электронный ресурс] : дис. ...канд. психол. наук : 19.00.01 / О.С. Ширяева. - Петропавловск-Камчатский, 2008. -254 c.

11. Шкала психологического благополучия Рифф [Электронный ресурс]. - Режим доступа: http://psylab.info/Шкала_психологического_благополучия_ Рифф.

12. Шамионов Р.М. Психология субъективного благополучия / P.М. Шамионов // Вопросы социальной психологии личности. - 2003. - № 4. - С. 27 41.

13. The Science of Well-Being: The Collected Works of Ed Diener. - Vol. 37. - Dordrecht - Heidelberg - London - New York: Springer, 2009. - 274 p. - (Social Indicators Research Series).

14. Diener E. Subjective Weil-Being: Three Decades of Progress / E. Diener, E.M. Suh, R.E. Lucas, H.L. Smith // Psychological Bulletin. - 1999. - Vol. 125. N.2. - pp. 276-302.

15. Lucas R.E. Personality and Subjective Well-Being / R.E. Lucas, E. Diener // Handbook of personality : theory and research / edited by O.P. John, R.W. Robins, 
L.A. Pervin. $-3^{\text {rd }}$. ed. - New York-London: Guilford Press, 2010. - Pp.795-814.

16. Ryff C. The Structure of Psychological Well-Being Revisited / C. Ryff // Journal of Personality and Social Psychology. - 1995. - Vol. 69. - № 4. - Pp. 719727.

\section{References transliterated}

1. Argajl M. Psihologija schast'ja / M. Argajl. - 2-e izd. - SPb.: Piter, 2003. 271 s. - (Serija «Mastera psihologii»).

2. Bocharova E.E. Vzaimosvjaz' cennostnyh orientacij, strategij povedenija i sub\#ektivnogo blagopoluchija lichnosti : avtoref. diss. ... kand. psihol. nauk : 19.00.05 / E.E. Bocharova. - Saratov, 2005. - 23 s.

3. Voronina A.V. Ocenka psihologicheskogo blagopoluchija shkol'nikov v sisteme profilakticheskoj i korrekcionnoj raboty psihologicheskoj sluzhby : avtoref. ... kand. psih. nauk : 19.00.04 / A.V. Voronina. - Irkutsk, 2002. - 28 s.

4. Kulikov L.V. Determinanty udovletvorennosti zhizn'ju / L.V. Kulikov // Obshhestvo i politika / Red. V.Ju. Bol'shakov. - SPb.: Izd-vo S.-Peterburgskogo unta, 2000. - S.476-510.

5. Leont'ev D.A. Lichnostnoe $\mathrm{v}$ lichnosti. Lichnostnyj potencial kak osnova samodeterminacii / D.A. Leont'ev // Uchenye zapiski kafedry obshhej psihologii MGU im. M.V.Lomonosova / Pod red. B.S. Bratusja, D.A. Leont'eva. - Vyp. 1. - M.: Smysl, 2002. - S.56-65.

6. Puchkova G.L. Sub\#ektivnoe Blagopoluchie kak faktor samoaktualizacii lichnosti [Jelektronnyj resurs] : dis. ...kand. psihol. nauk : 19.00.01 / G. L. Puchkova - M. : RGB, 2003. - $163 \mathrm{~s}$.

7. Smoleva E.O. Udovletvorennost' zhizn'ju i uroven' schast'ja: vzgljad sociologa [Tekst] : monografija / E.O. Smoleva, M.V. Morev; pod nauch. ruk. d.je.n. A.A. Shabunovoj. - Vologda : ISJeRT RAN, 2016. - 164 s. - (Problemy jeffektivnosti gosudarstvennogo upravlenija).

8. Stajl Sh. Pozitivnaja psihologija. Chto delaet nas schastlivymi, optimistichnymi i motivirovannymi / Sh.Stajl. - M.: Pretekst, 2013. - 326 s.

9. Fesenko P.P. Osmyslennost' zhizni i psihologicheskoe blagopoluchie 
lichnosti : avtoref. dis. ... kand. psihol. nauk: 19.00.01 / P.P. Fesenko. - M., 2005. $24 \mathrm{~s}$.

10. Shirjaeva O.S. Psihologicheskoe blagopoluchie lichnosti v jekstremal'nyh uslovijah zhiznedejatel'nosti [Jelektronnyj resurs] : dis. ...kand. psihol. nauk : 19.00.01 / O.S. Shirjaeva. - Petropavlovsk-Kamchatskij, 2008. - 254 s.

11. Shkala psihologicheskogo blagopoluchija Riff [Jelektronnyj resurs]. Rezhim dostupa: http://psylab.info/Shkala_psihologicheskogo_blagopoluchija_Riff.

12. Shamionov R.M. Psihologija sub\#ektivnogo blagopoluchija / R.M. Shamionov // Voprosy social'noj psihologii lichnosti. - 2003. - № 4. - S. 27-41.

13. The Science of Well-Being: The Collected Works of Ed Diener. - Vol. 37. - Dordrecht - Heidelberg - London - New York: Springer, 2009. - 274 p. - (Social Indicators Research Series).

14. Diener E. Subjective Weil-Being: Three Decades of Progress / E. Diener, E.M. Suh, R.E. Lucas, H.L. Smith // Psychological Bulletin. - 1999. - Vol. 125. N.2. - pp. 276-302.

15. Lucas R.E. Personality and Subjective Well-Being / R.E. Lucas, E. Diener // Handbook of personality : theory and research / edited by O.P. John, R.W. Robins, L.A. Pervin. $-3^{\text {rd }}$. ed. - New York-London: Guilford Press, 2010. - Pp.795-814.

16. Ryff C. The Structure of Psychological Well-Being Revisited / C. Ryff // Journal of Personality and Social Psychology. - 1995. - Vol. 69. - № 4. - Pp. 719727.

Отримано: 20.03 .2018

Відрецензовано: 02.04.2018

Опубліковано: 11.04.2018 